\title{
Evaluation of Office Chair Comfort
}

\section{Procjena udobnosti uredskih stolica}

\author{
Original scientific paper • Izvorni znanstveni rad \\ Received-prispjelo: 14. 3. 2016. \\ Accepted-prihvaćeno: 5. 5. 2016. \\ UDK: $630 * 836.1$ \\ doi:10.5552/drind.2016.1615
}

\begin{abstract}
The studies of office chair constructions have identified differences in perception of comfort provided by different types of seats. Four seat constructions and the comfort provided to the users were compared by means of subjective indicators. After a two-day sitting on each of the studied chairs, the subjects scored their perception of comfort and discomfort, using the questionnaire with 17 statements. Unlike most similar studies, subjects evaluated seats on their own work places and in the environment to which they are accustomed. Constructional forms of the seat and materials that contributed more to the sense of comfort by minimizing fatigue and pains developed by sitting were determined. Results have shown that the chair with a net is significantly more comfortable than other chairs. The chair with molded PUR foam is significantly more comfortable than the chair with springs, but statistically it does not differ significantly from the chair with slabstock PUR foam. It has been concluded that the chair with a net got higher scores, which might be attributed to its frame construction and the absence of a hard base under the sitting surface.
\end{abstract}

Keywords: subjective method, sitting, comfort, discomfort, office chair

SAŽETAK • Istraživanjem konstrukcija uredskih stolica utvrđene su razlike u osjećaju udobnosti sjedenja na različitim sjedalima. Uspoređene su četiri konstrukcije sjedala i njihove udobnosti za korisnika, $i$ to na temelju subjektivnih pokazatelja. Ispitanici su nakon dvodnevnog sjedenja na stolici ocjenjivali osjećaj udobnosti ili neudobnosti odgovarajući na upitnik sa 17 ponuđenih tvrdnji. Za razliku od većine sličnih istraživanja, ispitanici su ocjenjivali sjedala na svojim radnim mjestima i u okolini na koju su naviknuli. Ispitivanjem su određeni konstrukcijski oblik sjedala i materijali izrade stolica koje pridonose osjećaju veće udobnosti time što minimaliziraju osjećaj zamora i pojavu bolova pri sjedenju. Rezultati su pokazali da je stolica s mrežom znatno udobnija od ostalih. Stolica s hladno lijevanom PUR spužvom mnogo je udobnija od stolica s oprugama, ali se statistički ne razlikuje od stolica s rezanom PUR spužvom u sjedalu. Zaključeno je da je stolica s mrežom najbolje ocijenjena zbog njene okvirne konstrukcije i zato što ispod površine za sjedenje nema tvrde podloge.

Ključne riječi: subjektivna metoda, sjedenje, udobnost, neudobnost, uredska stolica

\section{INTRODUCTION \\ 1. UVOD}

Office work, as work performed in sitting position, requires sitting during most of the work time, with short walking and standing intervals (Hermenau, 1999; Wilder et al., 1996). According to Kapica and Grbac, the basic principle of a comfortable seat is contained in the system where the sitting bones take the body weight off, while the feet are not loaded and the spine main- tains its natural posture. Construction of upholstery, shape and hardness of the sitting surface, degree of the seat and backrest deformity, etc. along with the product's overall construction determine the sitting comfort and level of tiring (Kapica and Grbac, 1998). It is a known fact that most of us rather sit than stand, that sitting does not require as much muscular work as does standing and that it is much easier to work while sitting because it stabilizes postures (Lueder, 2004), the arms and hands can be used freely and it is also easy to oper-

\footnotetext{
${ }^{1}$ Authors are assistant professors and professor at the Faculty of Forestry, University of Zagreb, Croatia.

${ }^{1}$ Autori su docenti i profesor Šumarskog fakulteta Sveučilišta u Zagrebu, Zagreb, Republika Hrvatska.
} 
ate pedals or controls with the feet (Kroemer et al., 2003). However, according to Grandjean (quoted by Hermenau, 1999) sitting, unlike standing, increases the pressure to intervertebral discs up to $35 \%$. Other analytical studies addressed the pressure in the intervertebral discs as a function of trunk posture and body support (Kroemer et al., 2003). In addition, prolonged sitting can have many disadvantages, with long-term consequences to human health (van Deursen et al. 1999).

The debate in the literature concentrates on the difference between comfort and discomfort. De Looze et al. (2003) quote that several researches simply defined discomfort as the lack of comfort and vice versa (Hertzberg 1958; Floyd and Roberts 1958). Richards (1980), quoted by the same authors, stresses that comfort is the state of a person involving a sense of subjective well-being, in reaction to an environment or a situation. Other studies dealing with ergonomics, and in contrast with the concept of two discrete states, believe that comfort and discomfort are two opposites on a continuous scale, ranging from extreme discomfort through a neutral state to extreme comfort. The factors of comfort and discomfort can be classified into several sub-groups: impression, relief/energy, well-being, relaxation, and fatigue, restlessness, pain/biomechanics, strain and circulation. Discomfort is usually caused by biomechanical factors and fatigue (Zhang et al., 1996). According to Ljuljka (1976), humans sit while traveling, in the cinema and theatre and particularly throughout their schooling. For this very reason, the chairs, in addition to responding to contemporary trends and design, must provide comfort above all. It is not that easy to accurately define comfort of the furniture to sit on. There was a time when comfort was related to softness. Nowadays, it is accommodation to human body that counts. Quite true, soft furniture accommodates to human body, but that fact carries some additional problems. The basic factor of contemporary comfort is a specific pressure to the body. This pressure is smaller when the contact surface of human body is larger. It should be noted that the characteristics of upholstery are important for comfort and proper distribution of pressure (Ergić, 2002; Grbac and Ivelić, 2005). Thermal conductivity and humidity penetration to the upholstery are very important and significantly affect the comfort feeling (Vlaović et al., 2012). However, they have not been taken into consideration in this paper. The occurrence of CTDs (Cumulative Trauma Disorders) in the office environment has seen a tremendous increase in the recent years. While performing sedentary tasks, the worker should not feel any discomfort due to improper seating, that is, the worker should be in a state of non-awareness of the seat (Branton, 1969; quoted by Fernandez and Poonawala, 1998). Some of the aims of ergonomic sitting are to increase individual effectiveness, reduce tiredness and maintain the "correct" sitting posture. Improper sitting is the main cause of reduced performance during the work. Furniture users must not experience distracting pressure on their body. Furniture must allow the body to reach a desired posture, e.g. during lying on the bed, and if possible to achieve utmost comfort in that position (Grbac, 1984). The same principle can be applied to the seating furniture (Vlaović, 2005).

Along with the need to evaluate the chair suitability, the primary objective of Drury and Coury (1982) study (quoted by Fernandez and Poonawala, 1998) was to discover its strengths and weaknesses or to compare it directly to other chairs. Rating and ranking are the two most common methodologies for evaluating ergonomic office chairs. A questionnaire containing comfort and discomfort scales is valuable for determining if comfort and discomfort ratings exist as a bipolar continuum (Potter et al., 1998). The methodology of direct interview about comfort degree (Richards, 1980; quoted by de Looze et al., 2003) is very direct given that comfort/discomfort is a subjective perception. In the perception of comfort/discomfort, the factors of comfort become secondary as long as the factors of discomfort are present. Biomechanical discomfort factors increase as a function of time of day, and chair design did not seem to matter (Kleberg and Ridd, 1987). This explains why previous researchers have had difficulties in differentiating between chairs in ergonomic evaluations. Many authors have observed that chair users, seemingly unaware, change posture constantly, supposedly to relieve the buildup of body pressure and discomfort. For example, crossing legs and putting one leg on top of the other changes the pressure distribution under the ischial tuberosities (Helander and Zhang, 1997). Potter et al. (1998) have shown that it takes several hours to make an accurate evaluation of a chair. Proper ergonomic evaluation and identification of a chair comfort during 8-hour workday requires at least three hours (Fitzgerald et al., 1996). Due to the fact that comfort descriptors related to chair design are not affected by time, whereas comfort descriptors related to well-being and most discomfort descriptors are affected by time, it is difficult to propose a measurement procedure. One option is to only evaluate one chair per day at a standard (predefined) time. It has been proved (Zhang et al., 1996; Helander and Zhang, 1997) that both comfort and discomfort can be quantified independently, and the scales developed for the Chair Evaluation Checklist (CEC) provide consistent results, suitable for practical evaluation of chair comfort and discomfort.

Further to the above, subjective method was used in this paper with the use of modified CEC. The aim of the paper was to find connection between different seat designs of office chairs and their comfort/discomfort by subjective evaluation questionnaire.

\section{MATERIALS AND METHODS}

2. MATERIJALI I METODE

\subsection{Samples and subjects}

2.1. Uzorci $i$ ispitanici

The samples of ergonomic office chairs selected for the research were in accordance with the relevant European Norms (EN). The samples provided natural 


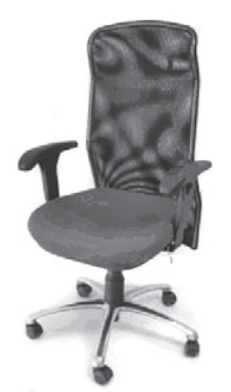

a) Model A

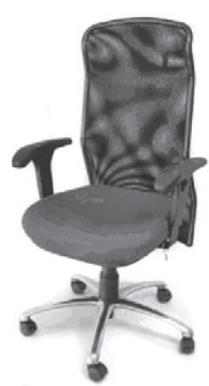

b) Model B

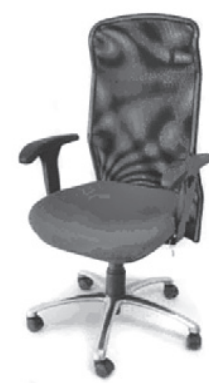

c) Model C

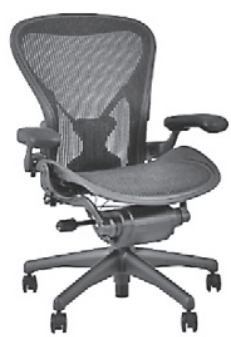

d) Model D

Figure 1 Chair models used in the study

Slika 1. Modeli stolica obuhvaćeni istraživanjem

and appropriate sitting posture and relative comfort achieved by mechanism, seat and backrest quality and shape, and by adjustable armrests. Study design included four (4) seemingly equal chair models, different in seat construction. All chairs were coded: Model A was the chair with the slabstock PUR foam in the seat (40 kg/ $\mathrm{m}^{3}$, thickness $50 \mathrm{~mm}$ ), Model B was the chair with the molded PUR foam in the seat $\left(40 \mathrm{~kg} / \mathrm{m}^{3}\right.$, thickness 50 $\mathrm{mm}$ ), Model $\mathrm{C}$ was the chair with the combination of the pocket micro-springs $\left(D_{\text {spring }} 45 \mathrm{~mm}, \mathrm{~d}_{\text {wire }} 1,6 \mathrm{~mm}\right.$, height $40 \mathrm{~mm})$ and molded PUR foam $\left(40 \mathrm{~kg} / \mathrm{m}^{3}\right.$, thickness 15 $\mathrm{mm}$ ), and Model D was the chair with the seat made of elastic net. The models are shown in Figure 1.

Thirty-six subjects (18 females and 18 male) from 22 to 60 years of age (mean 35.1; SD 9.7), with the height of 156 to $187 \mathrm{~cm}$ (mean 173.6; SD 8.6) and weight of 48 to $103 \mathrm{~kg}$ (mean 71.9; SD 12.8) participated in the study. Their jobs were mostly performed in sitting position, within the time-span of 3 months to 27 years. The subjects were grouped in nine syndicates of four. Before the experiment, subjects completed the questionnaire about their health problems, with the following results: headache $8 \%$, shoulder pain $11 \%$, neck pain $19 \%$, cervical spine pain $14 \%$, thoracic spine pain $3 \%$, lumbar spine pain $11 \%$, hip pain $0 \%$, legs pain - varicose veins $3 \%$, poor circulation $14 \%$, joint pain $6 \%$, leg swelling $8 \%$, knee pain $6 \%$ and epiphany of hemorrhoids $11 \%$. Nineteen persons (53 $\%$ ) did not report any health problem.

\subsection{Methods}

\subsection{Metode}

The method for this research is based on modified CEC questionnaire (original Chair Evaluation Checklist was developed by Helander and Zhang, 1997), some adjusted questions within CEC, and some additional questions (Vlaović, 2005). The questionnaire consists of 17 statements about comfort and discomfort, which were, contrary to the original CEC, mixed together. Besides, some questions were adapted to this study in order to emphasize the feeling obtained from the seat, not the chair: "The chair is spacious» was replaced by «The seat is spacious» and «The seat feels soft» instead of «The chair feels soft». The statement «I feel uncomfortable» was excluded, and: «I feel pain caused by sitting», «I feel cramped», «I feel numb» and «I feel calm» were added. Later in the statistical analysis, all statements were separated, like in

\section{I feel uneven pressure on thighs and buttocks

\begin{tabular}{lllllllll} 
Not at all & \multicolumn{3}{c}{ Moderately } & & & \multicolumn{2}{c}{ Extremely } \\
\hline 1 & 2 & 3 & 4 & 5 & 6 & 7 & 8 & 9
\end{tabular}

Figure 2 An example of the questionnaire question Slika 2. Primjer pitanja iz upitnika (s rasponom skale nimalo-umjereno-jako)

the original CEC, into those of comfort (6 statements) and those of discomfort ( 8 statements) in order to get inherent conclusions. Three of the above mentioned statements were later excluded from further statistical analysis to avoid potential bias, as they were not part of the original CEC.

The statements on comfort scale were the following ones: «The chair looks nice», «I like the chair», «The seat feels soft», «I feel relaxed», «The seat is big enough», «I feel restful», «I feel calm» and «I feel comfortable». The statements on discomfort scale were: «I feel tired», «I feel restless», «I have sore muscles», «I feel pain induced by seating», «I feel stiff», «I feel uneven pressure on thighs and buttocks», «I feel cramped», «I have heavy legs» and «I feel numb».

The answering order was not strict, but the answers had to be provided between 11 a.m. and midday. Each of 17 questions included a statement (e.g. I feel uneven pressure on thighs and buttocks) and the numbered line. To answer, subjects had to mark with «X» the respective place on the line (Figure 2).

Every subject tested four chairs, each over two working days according to the preset scheme: first day, the subjects adjusted the correct position and body position and started using a chair; on second day, after three hours of sitting, they had to complete the questionnaire. Afterwards they changed the chair and repeated a two-day cycle. They were also introduced to the research aim and to different seat cores. As in real office-work situations, posture was not fixed or controlled except necessary chair adjustment - according to the instructions of an expert.

\subsubsection{Testing of reliability and validity of comfort and discomfort scales}

2.2.1. Ispitivanje pouzdanosti i valjanosti skala udobnosti i neudobnosti

For the purpose of determining the reliability of created comfort and discomfort scales, statistical procedure was carried out to determine the reliability of the measuring instrument. The internal consistency cri- 
Table 1 Characteristics of comfort and discomfort scales Tablica 1. Obilježja skala udobnosti i neudobnosti

\begin{tabular}{|l|c|c|}
\hline & $\begin{array}{c}\text { Comfort } \\
\text { scale } \\
\text { Skala } \\
\text { udobnosti }\end{array}$ & $\begin{array}{c}\text { Discomfort } \\
\text { scale } \\
\text { Skala } \\
\text { neudobnosti }\end{array}$ \\
\hline $\begin{array}{l}\text { Arithmetical mean } \\
\text { Aritmetička sredina }\end{array}$ & 5.28 & 2.95 \\
\hline $\begin{array}{l}\text { Standard deviation } \\
\text { Standardna devijalcija }\end{array}$ & 0.56 & 0.82 \\
\hline Minimum / Minimum & 4.21 & 1.84 \\
\hline Maximum / Maksimum & 5.72 & 4.17 \\
\hline $\begin{array}{l}\text { Standardized Cronbach alpha } \\
\text { Standardizirani Cronbach alfa }\end{array}$ & 0.86 & 0.88 \\
\hline
\end{tabular}

terion Cronbach alpha was used to analyze reliability. Scale reliability testing was performed on overall results. In that way, for each statement of comfort scale (a total of 6) and each statement of discomfort scale (a total of 8), an average result was obtained for that particular statement. In accordance with the reviewed scale used by Helander and Zhang (1997), when creating scales, the statements "I feel cramped" and "The seat is big enough" were thrown out, and the statement "I feel comfortable" was not included in the comfort scale either, but it was used as a criterion variable during the processing. Based on the values of the consistency coefficient obtained (Cronbach alpha), it can be concluded that in both cases the scales are highly reliable in measurement (Table 1).

Another measurement characteristic is validity. The statement "I feel comfortable" was treated as a criterion variable, and for correlation testing of the comfort scale results, discomfort scale results and the statement "I feel comfortable" a Pearson $r$ correlation coefficient was used. According to the correlations ob- tained, the following can be concluded: (1) there is statistically significant negative correlation of medium strength between the comfort scale and discomfort scale $(r=-0.55 ; p<0.01)$, which is in accordance with the hypothetical model of comfort and discomfort suggested by Zhang et al. (1996); (2) correlation between the comfort scale and the statement "I feel comfortable" is statistically significant and high $(r=0.76 ; p<$ 0.01 ) and of positive sign, and (3) correlation between the discomfort scale and the statement "I feel comfortable" is statistically significant, of medium strength and of negative sign $(r=-0.56 ; p<0.01)$.

The reliability results of the comfort and discomfort scales, as well as validity of measurement, verified via correlation with the statement "I feel comfortable", have confirmed the obtained results and enabled the use of these scales to verify the influence of different construction of office chair seats based on subjective experience of comfort.

\section{RESULTS}

\section{REZULTAT}

\subsection{Evaluation of comfort and discomfort}

3.1. Procjene udobnosti i neudobnosti

Subjective evaluation through the questionnaire was compiled on the level of a statement and divided by total number of subjects (36) in order to get the average result for a specific statement evaluation. Complete results are published in Vlaović et al. (2008).

Given the fact that evaluation factor referred to comfort and discomfort, i.e. varied at two levels, whereas the chair factor varied at four levels (Models A, B, C and D), eight MANOVA variables were developed to check the effect of each chair on the evaluation of comfort/discomfort. Figure 3 shows the results of evaluation of each chair discomfort and comfort.

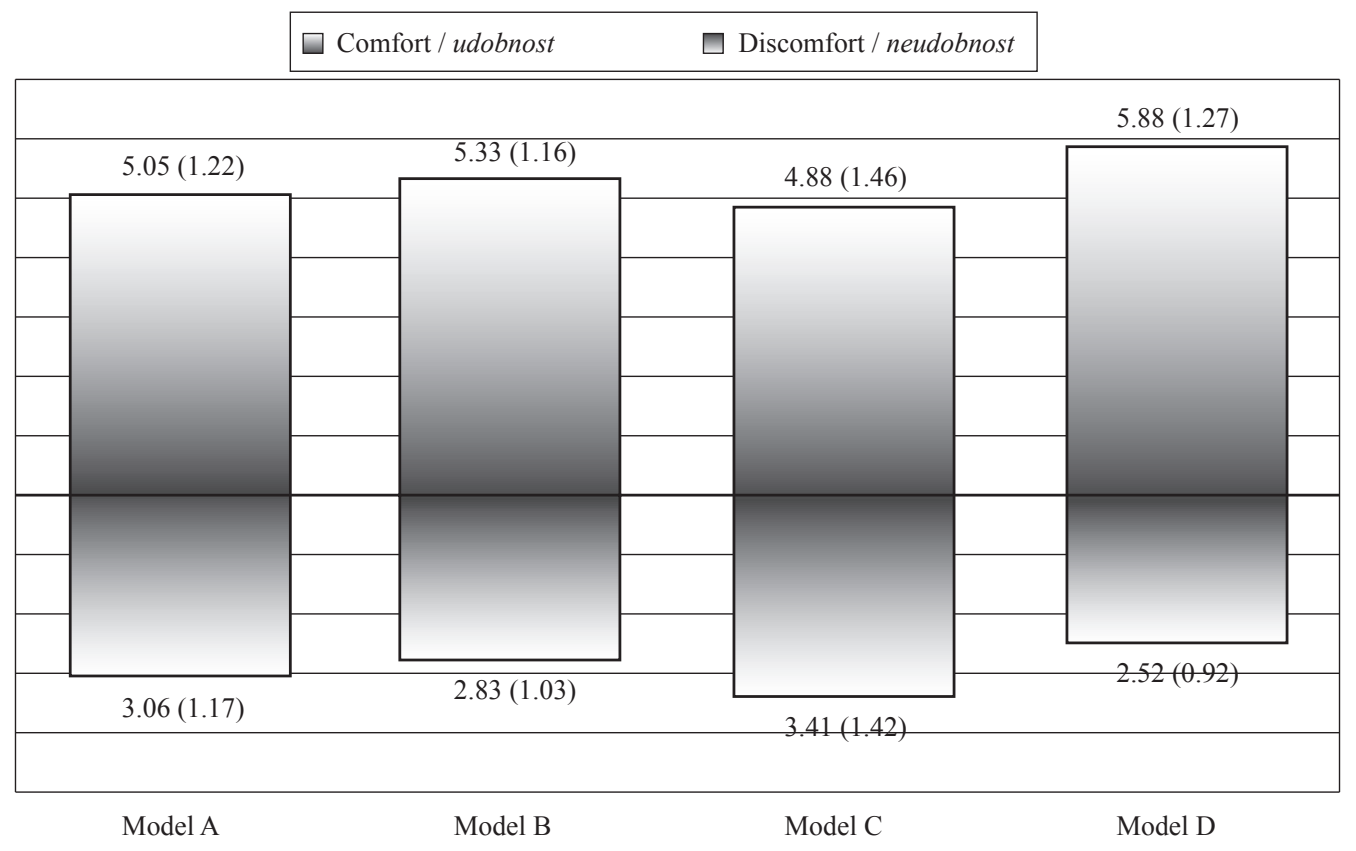

Figure 3 Average scores (and standard deviations) of comfort and discomfort - MANOVA variables Slika 3. Prosječne ocjene (i standardne devijacije) udobnosti i neudobnosti - MANOVA varijable 
Table 2 MANOVA - significance of tested differences Tablica 2. MANOVA - značajnost testiranih razlika

\begin{tabular}{|l|c|c|}
\hline & $\boldsymbol{F}$ & $\boldsymbol{p}^{*}$ \\
\hline Scales / Skale & 79.202 & 0.00 \\
\hline Chairs / Stolice & 2.531 & 0.12 \\
\hline Scales * Chairs / Skale * stolice & 5.259 & 0.03 \\
\hline
\end{tabular}

${ }^{*} p=$ significance of differences / značajnost razlike

\subsection{The differences in evaluation due to seat} construction and material

3.2. Razlike u procjenama s obzirom na konstrukciju i materijal sjedala

The data were processed by statistical software SPSS 10.0.7. Significance of differences in subjective evaluation of comfort and discomfort was checked by multivariate analysis of variance (MANOVA) with repetitive measuring of two factors - evaluation and chair (Table 2).

In evaluating all studied chairs, the scores for comfort on the respective scale were significantly higher than those for discomfort on the respective scale. This means that the subjects scored all chairs as more comfortable than uncomfortable.

Evaluation interaction on scales and on chairs was statistically significant. In order to determine on which scale evaluations are significantly different, a post-hoc analysis with t-test for dependent samples was carried out. $T$-test results are given in Table 3 .

According to the below table, in testing differences in comfort evaluation between Model D and Model $\mathrm{C}$, the first one has shown to be significantly more comfortable $(t=3.58 ; p=0.00)$; in testing differences in discomfort evaluation between Model D and Model C, the second one has shown to be significantly more uncomfortable $(t=-3.66 ; p=0.00)$; in testing differences in comfort evaluation between Model D and Model B, the first one has shown to be significantly more comfortable $(t=2.61 ; p=0.01)$; while in testing differences in discomfort evaluation between Model D and Model B, there has been no significant difference, etc.

Table $3 T$-test of significant evaluation differences of chairs on comfort and discomfort scales

Tablica 3. Testiranje značajnosti razlika u procjenama stolica na skalama udobnosti i neudobnosti $t$-testom

\begin{tabular}{|l|c|c|c|c|}
\hline & \multicolumn{2}{|c|}{$\begin{array}{c}\text { Comfort } \\
\text { scale } \\
\text { Skala } \\
\text { udobnosti }\end{array}$} & \multicolumn{2}{c|}{$\begin{array}{c}\text { Discomfort } \\
\text { scale } \\
\text { Skala } \\
\text { neudobnosti }\end{array}$} \\
\cline { 2 - 5 } & $t$ & $p$ & $t$ & $p$ \\
\hline Model D vs. Model C & 3.58 & $0.00^{*}$ & -3.66 & $0.00^{*}$ \\
\hline Model D vs. Model B & 2.61 & $0.01^{*}$ & -1.58 & 0.12 \\
\hline Model D vs. Model A & 3.14 & $0.00^{*}$ & -2.24 & $0.03^{*}$ \\
\hline Model C vs. Model B & -2.11 & $0.04^{*}$ & 2.62 & $0.01^{*}$ \\
\hline Model C vs. Model A & -1.00 & 0.32 & 1.48 & 0.15 \\
\hline Model B vs. Model A & 1.52 & 0.14 & -1.09 & 0.28 \\
\hline
\end{tabular}

*The differences are statistically significant at $5 \%$. / Razlike su statistički značajne na razini $5 \%$.

\section{DISCUSSION AND CONCLUSION 4. RASPRAVA I ZAKLJUČAK}

The reliability results of the comfort and discomfort scales and validity of measurements via internal consistency Cronbach alpha and Pearson r correlation coefficient with the statement "I feel comfortable", have confirmed the results obtained so far. Those facts enabled the use of comfort and discomfort scales for the verification of different constructions of office chairs based on personal experience of comfort.

T-test for dependent samples has shown that the Model D is significantly more comfortable than other chairs. Model B is significantly more comfortable than the Model C, but statistically it does not differ significantly from the Model A. The rank of studied seat constructions/chairs by comfort is as follows: a seat with a net (D - the most comfortable seat), a seat with molded PUR foam/seat with PUR foam (B/A) and a seat with springs $(\mathrm{C}-$ the least comfortable seat).

Also, statistically significant differences have been obtained by evaluation on a discomfort scale. Significant differences appear in evaluation of the chairs with a net, with springs and with PUR foam. The difference in evaluated discomfort of Model D and Model B is not statistically significant. Significant is the difference between the evaluated discomfort of Model C and Model B, where the former one is scored significantly higher on the discomfort scale. The rank of studied seat constructions/chairs by discomfort is as follows: a seat with springs $(\mathrm{C}$ - the most uncomfortable seat), a seat with PUR foam (A) and a seat with molded PUR foam/a seat with a net (B/D - the least uncomfortable seat).

It should be noted that the subjects showed more preference for the statements about aesthetic characteristics of the chairs that were closely related to the comfort scale, rather than to discomfort scale, which can be verified in Vlaović (2005). It has been concluded that the chair with a net got higher scores, which might be attributed to its frame construction and the absence of a hard base under the sitting surface. This fact, along with good elasticity of the net, enables uniform and desirable pressure distribution. On the other hand, the chair with the most common seat design (slabstock foam) proved to be the next favorite. The reason for that can be found in the thickness of the seat foam (50 $\mathrm{mm}$ ). The same explanation can be applied to a molded seat. Although all chairs (except the one with the net) had an even seat thickness, in the seat with springs, the layer of the PU foam was only $15 \mathrm{~mm}$. As a result of the user's body load, the seat reached bottom-out (lack of support under full weight load) very quickly, and therefore users felt discomfort.

Unquestionably, support must be given to further similar interdisciplinary research on materials and constructions, which are inherently different from the top scored netted model in this study and which provide significantly less differences in perception of comfort than do the available ones. That joint consideration of the furniture mostly used during daytime must be designed so as to provide comfort and prevent various disorders of the spine, joints, blood circulation, allergies, etc. 


\section{Acknowledgements - Zahvala}

This research was supported by University of Zagreb, Faculty of Forestry, Department for Furniture and Wood Products. The authors are grateful to Anaks d.o.o. Zagreb and Tapo d.o.o. Zagreb for technical support.

\section{REFERENCES}

5. LITERATURA

1. Deursen, L. L. van; Patijn, J.; Durinck, J. R.; Brouwer, R.; Erven-Sommers, J. R. van; Vortman, B. J., 1999: Sitting and low back pain: The positive effect of rotatory dynamic stimuli during prolonged sitting. European Spine Journal, 8 (3): 187-193. http://dx.doi.org/10.1007/s005860050155.

2. Ergić, T., 2002: Contribution to research in pressure distribution on contact surfaces - doctoral thesis (in Croatian). University of Zagreb, Faculty of Mechanical Engineering and Naval Architecture, Zagreb.

3. Fernandez, J. E.; Poonawala, M. F., 1998: How long should it take to evaluate seats subjectively? Int. J. Ind. Erg., 22, 483-487. http://dx.doi.org/10.1016/s0169-8141(97)90014-7.

4. Fitzgerald, S. J.; Kult, K. M.; Skubic, C. R.; Fernandez, J. E.; Poonawala, M. F., 1996: The optimum time to evaluate the comfort rating of seats. In: Mital, A.; Krueger, H.; Kumar, S.; Menozzi, M.; Fernandez, J. E. (eds.): Advances in Occupational Ergonomics and Safety I (vol. 2). International Society for Occupational Ergonomics and Safety, Cincinnati, 820-825.

5. Grbac, I., 1984: Research of durability and elasticity of different mattress construction - master thesis (in Croatian). University of Zagreb, Faculty of Forestry, Zagreb.

6. Grbac, I.; Ivelić, Ž., 2005: Upholstered furniture, first ed. University of Zagreb, Faculty of Forestry, Academy of Forestry Science, Zagreb.

7. Helander, M. G.; Zhang, L., 1997: Field studies of comfort and discomfort in sitting. Ergonomics 40, 895-915. http://dx.doi.org/10.1080/001401397187739.

8. Hermenau, D. C., 1999: Seating. Ergonomics for therapists, 219-237.

9. Kapica, L.; Grbac, I., 1998: Construction principles of ergonomic furniture intended for sitting and lying (in Croatian). In: Grbac, I. (ed.): Furniture and healthy habitation. Proceedings of international conference. University of Zagreb, UFI-Paris, Zagreb, 53-58.

10. Kleberg, I. G.; Ridd, J. E., 1987: An evaluation of office seating. Contemporary Ergonomics. Robens Institute, University of Surrey, Guildford, UK, 203-208.
11. Kroemer, K.; Kroemer, H.; Kroemer-Elbert, K., 2003: Ergonomics: how to design for ease and efficiency, second ed. Prentice Hall Inc., New Jersey.

12. Looze, de, M. P.; Kujit-Evers, L. F. M.; Van Dieen, J., 2003: Sitting comfort and discomfort and the relationships with objective measures. Ergonomics 46: 985-997. http://dx.doi.org/10.1080/0014013031000121977.

13. Lueder, R., 2004: Ergonomics of seated movement, A review of the scientific literature: Considerations relevant to the $\operatorname{Sum}^{\mathrm{TM}}$ chair (written for Allsteel). URL:http:// www.humanics-es.com.

14. Ljuljka, B., 1976: Furniture for sitting, some of its characteristic and testing methods (in Croatian). Drvna industrija 27: 13-20.

15. Potter, D. W.; Fortier, C. J.; Rigby, W. A.; Stevenson, J. M., 1998: Development and analysis of a comparative evaluation methodology for office chairs. In: Proceedings of the 30th Annual Conference of the Human Factors Association of Canada. HFAC, Mississauga, 195-199.

16. Vlaović, Z., 2005: Study of the office chairs comfort master thesis (in Croatian). University of Zagreb, Faculty of Forestry, Zagreb.

17. Vlaović, Z.; Bogner, A.; Grbac, I., 2008: Comfort evaluation as the example of anthropotechnical furniture design. Collegium antropologicum, 32 (1): 277-283.

18. Vlaović, Z.; Domljan, D.; Grbac, I., 2012: Research of Temperature and Moisture during Sitting on Office Chairs. Drvna industrija, 63 (2): 105-112. http://dx.doi.org/10.5552/drind.2012.1139.

19. Zhang, L.; Helander, M. G.; Drury, C. G., 1996: Identifying factors of comfort and discomfort in sitting. Human Factors 38: 377-389. http://dx.doi.org/10.1518/001872096778701962.

20. Wilder, D. G.; Aleksiev, A. R.; Magnusson, M. L.; Pope, M. H.; Spratt, K. F.; Goel, V. K., 1996: Muscular response to sudden load. A tool to evaluate fatigue and rehabilitation. Spine, 21 (22): 2628-2639.

http://dx.doi.org/10.1097/00007632-199611150-00013.

\section{Corresponding author:}

Assist. Prof. ZORAN VLAOVIĆ, Ph.D.

University of Zagreb

Faculty of Forestry

Svetošimunska 25, p.o. box 422

HR-10002 Zagreb

e-mail: zvlaovic@sumfak.hr 